\title{
An Overview of Therapeutic Options in Relapsing-remitting Multiple Sclerosis
}

\author{
Sidra Saleem ${ }^{1}$, Arsalan Anwar ${ }^{2}$, Muniba Fayyaz ${ }^{3}$, Fatima Anwer ${ }^{4}$, Faria Anwar ${ }^{5}$ \\ 1. Neurology, University of Toledo, Toledo, USA 2. Neurology, University Hospitals Cleveland Medical Center, \\ Cleveland, USA 3. Internal Medicine, Fatima Memorial Hospital, Lahore, PAK 4. Family Medicine, King Edward Medical \\ College, Lahore, PAK 5. Internal Medicine, Shifa International Medical College, Islamabad, PAK
}

Corresponding author: Sidra Saleem, sidra.msaleem.1@gmail.com

\begin{abstract}
Multiple sclerosis (MS) is a chronic disorder of the central nervous system (CNS). MS affects 2.1 million individuals every year and is also considered a major cause of economic health burden around the world. Genetics and environmental factors both play a role in the pathogenesis of MS by activating the immune response and causing inflammation. Patients with MS can have various clinical courses, but the most common pattern seen is relapsing-remitting multiple sclerosis (RRMS). Multiple therapeutic options have been studied to prevent RRMS patients from frequent relapses. The oldest and most frequently used medication for MS is interferon beta, either used alone or as add-on therapy with other drugs. Newer treatment options that have been recently approved to control MS symptoms and suppress the inflammation are glatiramer acetate and siponimod. Infusion therapies consisting of monoclonal antibodies and immunosuppressive drugs have also been studied in the recent past. Some trials have been conducted on the use of stem cells for RRMS patients. We have briefly discussed all treatment options and the response of RRMS patients in multiple trials.
\end{abstract}

Categories: Neurology, Pathology, Allergy/Immunology

Keywords: relapsing remitting multiple sclerosis, demyelination, autoimmune, therapeutics, deep brain lesions

\section{Introduction And Background}

Multiple sclerosis (MS) is a chronic central nervous system (CNS) disorder with widespread primary demyelination, inflammation, and progressive neurodegeneration [1]. The prevalence of MS has been rising since the last decade, affecting about 400,000 individuals every year in the U.S. and 2.1 million individuals around the world, with a male to female ratio of 2.5:1. The direct and indirect costs of MS on US healthcare ranged from $\$ 8,528$ to $\$ 52,244$ per patient per year [2].

Received 07/17/2019

Review began 07/25/2019 Review ended 07/25/2019 Published 07/26/2019

\section{๑) Copyright 2019}

Saleem et al. This is an open access article distributed under the terms of the Creative Commons Attribution License CC-BY 3.0., which permits unrestricted use, distribution, and reproduction in any medium, provided the original author and source are credited.
The exact etiology and pathogenesis of MS are uncertain, but both genetic and environmental factors contribute to disease development. Genetic factors are associated with the activation of the immune system, involving both an innate and an adaptive pathway while environmental factors include viral infections such as Epstein Barr virus, vitamin deficiency, and smoking. The commonly suggested hypothesis is that infection within CNS or neural disturbance initiates the development of the disease, leading to immune cell activation and disease progression [3]. This autoimmune etiology is the target of the therapeutic approach to MS patients, but many patients still face relapses and continuous deterioration, progression, brain atrophy, and new magnetic resonance imaging (MRI) lesions. Our objective is to describe the comprehensive overview of different therapy options for these relapse patients and to give the reader a better understanding of the treatment approach in these patients.

\section{Review}

\section{Types of multiple sclerosis}

Patients with MS may have a different clinical course. In most patients, the disease presents as the relapsing-remitting course (RRMS). It is the most prevalent form, affecting $85 \%$ of individuals. RRMS is marked by discrete, day-to-week attacks, followed by a week-to-month symptom-free interval. RRMS can progress to secondary progressive multiple sclerosis (SPMS) that is characterized by an initial relapse, followed by gradual neurologic deterioration. Many patients can present with primary progressive disease (PPMS) with a slow decline from the start. In a very few patients, the disease manifests as a continuous decline in function from the onset and later by an acute attack defined as progressive relapsing multiple sclerosis (PRMS) [4].

\section{Treatment of relapsing-remitting multiple sclerosis}

The National MS Society has identified more than 136 studies to evaluate the different therapeutic options for MS. Food and Drug Administration (FDA) has approved the following drugs for RRMS, which will be discussed in detail [5]. 


\section{Cureus}

1) Injectables (Interferon and Glatiramer Acetate)

2) Oral Therapies (Fingolimod, Teriflunomide, Dimethyl fumarate, Siponimod, Cladribine)

3) Infusion Therapies (Natalizumab, Ocrelizumab, Alemtuzumab, and Rituximab)

4) Other (Azathioprine, Laquinimod, Cyclophosphamide, Daclizumab, Dalfampridine, Mitoxantrone, Glucocorticoids, Intravenous immunoglobulin (IVIG), Dalfampridine)

\section{Injectables}

Interferon-Beta

This drug was approved for MS therapy by the FDA in 1993. Its mechanism of action is multifold and includes the inhibition of T-cell activation and a decrease in the activity of matrix metalloproteinase. It decreases proinflammatory cytokines and leads to the production of anti-inflammatory cytokines by increasing the activity of suppressor T-cells [6].

Route of administration: Subcutaneous/intramuscular

The literature search and original articles for the treatment of interferon-beta in RRMS are summarized below (Table 1).

\begin{tabular}{|c|c|c|c|}
\hline $\begin{array}{l}\text { Study, } \\
\text { country }\end{array}$ & $\begin{array}{l}\text { Sample } \\
\text { size, } \\
\text { duration }\end{array}$ & Methodology & Results \\
\hline $\begin{array}{l}\text { Calabresi } \\
\text { et al. [7], } \\
2014 \text {, } \\
\text { involved } 26 \\
\text { countries. }\end{array}$ & $\begin{array}{l}1516 \\
\text { patients, } \\
2 \text { years. }\end{array}$ & $\begin{array}{l}\text { It was a double-blind, phase III, placebo-controlled design for } 48 \text { weeks. } \\
\text { Patients were randomly assigned as } 500 \text { to Placebo, } 512 \text { to Pegylated } \\
\text { Interferon (PEG-INF) every } 2 \text { weeks group and } 500 \text { patients to PEG-INF } \\
\text { every } 4 \text { weeks group. The primary endpoint at } 48 \text { weeks was measured. }\end{array}$ & $\begin{array}{l}\text { After } 48 \text { weeks, PEG-INF group had fewer } \\
\text { relapses than the placebo group. }\end{array}$ \\
\hline $\begin{array}{l}\text { Moccia et } \\
\text { al. [8], } \\
\text { 2017, Italy. }\end{array}$ & $\begin{array}{l}507 \\
\text { patients, } \\
8.5 \pm 3.9 \\
\text { years. }\end{array}$ & $\begin{array}{l}\text { Subjects were divided into } 3 \text { groups, } 37 \% \text { were given subcutaneous } \\
\text { Interferon- } \beta 1 \text { a } 44 \mathrm{mcg}, 33.4 \% \text { with intramuscular Interferon- } \beta 1 \text { a } 30 \mathrm{mcg} \text {, } \\
\text { and } 29.0 \% \text { with subcutaneous Interferon- } \beta 1 \mathrm{~b} 250 \mathrm{mcg} \text {. }\end{array}$ & $\begin{array}{l}\text { Formulation, frequency, and dosage of } \\
\text { Interferon- } \beta 1 \text { a can affect long-term clinical } \\
\text { efficacy as a } 44 \text { mcg group showed more } \\
\text { reduction in disability as compared to two } \\
\text { other groups. }\end{array}$ \\
\hline $\begin{array}{l}\text { Drulovic et } \\
\text { al. [9], } \\
2013 \text {, } \\
\text { Europe. }\end{array}$ & $\begin{array}{l}419 \\
\text { patients, } 7 \\
\text { years. }\end{array}$ & $\begin{array}{l}\text { Subjects were divided into two groups, } 236 \text { IFN-beta-treated, and } 183 \\
\text { control. They were followed for } 7 \text { years and the number of relapses was } \\
\text { noted. }\end{array}$ & $\begin{array}{l}\text { The group treated with interferon showed a } \\
\text { significant reduction in progression to } \\
\text { secondary progressive MS. }\end{array}$ \\
\hline $\begin{array}{l}\text { Saida et al. } \\
\text { [10], 2016, } \\
\text { Japan. }\end{array}$ & $\begin{array}{l}100 \\
\text { patients, } \\
2 \text { years. }\end{array}$ & $\begin{array}{l}\text { All subjects were given intramuscular IFN beta-1a, one was given } \\
\text { intramuscular } 30 \mathrm{mcg} / \mathrm{weekly} \text { and other was given } 15 \mathrm{mcg} / \text { week for } 2 \\
\text { weeks and then } 30 \mathrm{mcg} / \text { week. }\end{array}$ & $\begin{array}{l}\text { Intramuscular Interferon has reduced the } \\
\text { relapsing rate with a good safety profile. }\end{array}$ \\
\hline $\begin{array}{l}\text { Traboulsee } \\
\text { et al. [11], } \\
2018, \\
\text { Canada }\end{array}$ & $\begin{array}{l}560 \\
\text { patients, } \\
1 \text { year. }\end{array}$ & $\begin{array}{l}\text { Subjects were divided into } 3 \text { groups, One group with IFN } \beta-1 \text { a } \\
\text { subcutaneously } 44 \mu \mathrm{g} \text {, second group with IFN } \beta-1 \text { a subcutaneously } 22 \\
\mu \mathrm{g} \text { three times weekly and the third group as placebo-controlled. All } \\
\text { were followed for a year and clinical and radiological improvement was } \\
\text { compared. }\end{array}$ & $\begin{array}{l}\text { Clinical and radiological improvement with } \\
\text { no evidence of disease activity was noted in } \\
\text { Interferon group as compared to placebo. }\end{array}$ \\
\hline RRMS: relaps & & trials for the use of interteron-beta in RRIMS & \\
\hline
\end{tabular}

Glatiramer Acetate

Glatiramer acetate (GA) was approved for the treatment of RRMS by the FDA in 2018. Its mechanism of action is two-fold, immunomodulatory and neuroprotective. Its immunomodulatory action is due to its competition by binding to antigen-presenting cells, driving B-cells, monocytes, and dendritic cells towards an anti-inflammatory response, induction of T-regulatory/Th2/Th3 cells, and down-regulating Th17/Th1 


\section{Cureus}

cells. Its neuroprotective effect is due to the secretion of neurotrophic factors that help in remyelination [12].

Route of administration: Subcutaneous

The literature search and original articles for the use of GA in RRMS are summarized below (Table 2).

\begin{tabular}{|c|c|c|c|}
\hline Year, Study & $\begin{array}{l}\text { Sample } \\
\text { size, } \\
\text { Duration }\end{array}$ & Methodology & Results \\
\hline $\begin{array}{l}\text { Rio et al. [13], } \\
2014, \text { Spain. }\end{array}$ & $\begin{array}{l}151 \\
\text { patients, } \\
1 \text { year. }\end{array}$ & $\begin{array}{l}\text { GA was given to patients with RRMS and followed for one year. } \\
\text { Clinical and radiological activities were noted. }\end{array}$ & $\begin{array}{l}\text { Patients treated with GA has improved clinical } \\
\text { and radiological findings. }\end{array}$ \\
\hline $\begin{array}{l}\text { Wolinsky et al. } \\
\text { [14], 2015, } 31 \\
\text { states of the } \\
\text { US. }\end{array}$ & $\begin{array}{l}209 \\
\text { patients, } \\
4 \\
\text { months. }\end{array}$ & $\begin{array}{l}\text { Subjects were randomized in 1:1 ratio to GA } 20 \mathrm{mg} / \mathrm{ml} \text { and GA } \\
40 \mathrm{mg} / \mathrm{ml} \text { group and were followed for } 4 \text { months and relapses } \\
\text { were noted. }\end{array}$ & $\begin{array}{l}\text { The response rate was better in patients taking } \\
40 \mathrm{mg} \mathrm{GA} \text {. }\end{array}$ \\
\hline $\begin{array}{l}\text { Ziemssen et al. } \\
\text { [15], 2014, } 148 \\
\text { centers } \\
\text { worldwide. }\end{array}$ & $\begin{array}{l}672 \\
\text { patients, } \\
24 \\
\text { months. }\end{array}$ & $\begin{array}{l}\text { All RRMS patients that were on any kind of disease-modifying } \\
\text { therapy were included. Their therapy was converted to } 20 \\
\mathrm{mg} / \mathrm{ml} \text { GA. Patients were assessed at baseline and at } 6,12,18 \\
\text { and } 24 \text { months. }\end{array}$ & $\begin{array}{l}\text { Results showed that with the conversion to GA, } \\
\text { patients showed improvement in cognition, } \\
\text { fatigue, and quality of life and their disability } \\
\text { scale was stable. }\end{array}$ \\
\hline $\begin{array}{l}\text { Davis et al. } \\
{[16], 2017,17} \\
\text { countries. }\end{array}$ & $\begin{array}{l}1404 \\
\text { patients, } \\
1 \text { year. }\end{array}$ & $\begin{array}{l}\text { Patients with RRMS was given GA } 40 \mathrm{mg} / \mathrm{ml} \mathrm{mg} \text { and followed } \\
\text { clinically and radiologically. }\end{array}$ & $\begin{array}{l}\text { GA decreased } 30 \% \text { of relapse within } 2 \text { months of } \\
\text { therapy }\end{array}$ \\
\hline $\begin{array}{l}\text { Zipser et al. } \\
\text { [17], 2015, } \\
\text { Australia }\end{array}$ & $\begin{array}{l}19 \\
\text { patients, } \\
24 \\
\text { months }\end{array}$ & $\begin{array}{l}12 \text { patients with RRMS were started on GA and } 7 \text { patients as } \\
\text { control were included. All patients were followed for } 24 \text { months. }\end{array}$ & $\begin{array}{l}\text { The results of this study contradict the } \\
\text { neuroprotective effect of GA and do not show an } \\
\text { improvement in paraclinical markers. }\end{array}$ \\
\hline
\end{tabular}

\section{TABLE 2: Clinical trials for the use of glatiramer acetate (GA) in RRMS}

RRMS: relapsing-remitting course

\section{Oral therapies}

The following five oral drugs have been approved by the FDA for the treatment of RRMS.

Fingolimod

Fingolimod was first approved by the FDA in 2010. It is an analog of sphingosine and thereby modulates the sphingosine-1-phosphate receptor that alters the migration and sequestration of lymphocytes in the lymph nodes [18].

Route of administration: Oral

The literature search and original articles for the use of fingolimod in RRMS are summarized below (Table 3). 


\section{Cureus}

\begin{tabular}{|c|c|c|c|}
\hline Year, Study & $\begin{array}{l}\text { Sample } \\
\text { Size, } \\
\text { Duration }\end{array}$ & Methodology & Results \\
\hline $\begin{array}{l}\text { Kappos et } \\
\text { al. [19], } \\
2015 \text {, } \\
\text { Switzerland. }\end{array}$ & $\begin{array}{l}1272 \\
\text { patients, } \\
2 \text { years. }\end{array}$ & $\begin{array}{l}\text { The primary endpoint was annualized relapse rate and the secondary } \\
\text { endpoint was time to disability progression. }\end{array}$ & $\begin{array}{l}\text { Relapse rate, the risk of disability } \\
\text { progression and end points on MRI were } \\
\text { improved with both doses ( } 0.5 \text { and } \\
1.25 \mathrm{mg} \text { ) as compared to Placebo. }\end{array}$ \\
\hline $\begin{array}{l}\text { Saida et al. } \\
\text { [20], 2012, } \\
\text { Japan. }\end{array}$ & $\begin{array}{l}171 \\
\text { patients, } \\
6 \\
\text { months. }\end{array}$ & $\begin{array}{l}\text { All patients with RRMS either received } 0.5 \mathrm{mg} \text { or } 1.25 \mathrm{mg} \text { of Fingolimod or } \\
\text { placebo daily. The primary endpoint was the percentage of patients with a } \\
\text { Gadolinium-enhanced lesion at } 3 \text { and } 6 \text { months and the secondary } \\
\text { endpoint was relapsed at } 6 \text { months. }\end{array}$ & $\begin{array}{l}\text { Relapse rate and Gadolinium lesions were } \\
\text { improved in Fingolimod group as } \\
\text { compared to placebo. }\end{array}$ \\
\hline $\begin{array}{l}\text { Kappos et } \\
\text { al. [21], } \\
2006 \\
\text { Switzerland. }\end{array}$ & $\begin{array}{l}281 \\
\text { patients, } \\
6 \\
\text { months. }\end{array}$ & $\begin{array}{l}\text { All patients with MS are given fingolimod at a dose of } 1.25 \text { or } 5.0 \mathrm{mg} \text { or } \\
\text { placebo. Primary Endpoint was the total number of Gadolinium-enhanced } \\
\text { MRI at monthly intervals for } 6 \text { months and clinical evaluations. }\end{array}$ & $\begin{array}{l}\text { After } 6 \text { months, Fingolimod reduced the } \\
\text { number of lesions on MRI and improved } \\
\text { clinical outcome at both doses as } \\
\text { compared to Placebo. }\end{array}$ \\
\hline $\begin{array}{l}\text { Cohen et al. } \\
\text { [22], 2010, } \\
\text { USA. }\end{array}$ & $\begin{array}{l}1292 \\
\text { patients, } \\
1 \text { year. }\end{array}$ & $\begin{array}{l}\text { Patients were given either } 1.25 \mathrm{mg} \text { or } 0.5 \mathrm{mg} \text { of Fingolimod daily or } 30 \mathrm{mcg} \\
\text { of intramuscular interferon beta-1a. The primary endpoint was annualized } \\
\text { relapse rate and the secondary endpoint was a new lesion in MRI after } 12 \\
\text { months. }\end{array}$ & $\begin{array}{l}\text { The trial showed Fingolimod improved } \\
\text { outcomes with respect to relapse rate and } \\
\text { MRI findings, in comparison with } \\
\text { Interferon beta-1a. }\end{array}$ \\
\hline
\end{tabular}

TABLE 3: Clinical trials for the use of fingolimod in RRMS

RRMS: relapsing-remitting course

Dimethyl Fumarate

Dimethyl fumarate (DMF) was approved by the FDA in March 2013. Its complete mechanism of action is not fully understood yet, although its neuroprotective and anti-inflammatory properties are due to the activation of Nrf2 pathways [23]. Multiple studies were conducted to show the effectiveness of DMF. Fox et al. [24] conducted a study by including 1400 patients with RRMS and were given DMF $480 \mathrm{mg}, 720 \mathrm{mg}$, and subcutaneous GA $20 \mathrm{mg}$ or placebo in a ratio of 1:1:1:1. Patients were followed for two years and the number of relapses was noted. After the completion of the study, both doses of DMF and GA proved to be more effective in reducing the relapse rate and improving neuroradiologic findings [24]. In 2010, another study in Germany showed the same result [25]. DMF treatment may decrease the lymphocyte count, and if lymphopenia develops, it is recommended to stop DMF. Another concern is liver injury, which can lead to increased aminotransferase [26].

\section{Teriflunomide}

This drug was approved by the FDA in September 2012. It works as an immunomodulator and is the active leflunomide metabolite that inhibits the biosynthesis of pyrimidine and disrupts the interaction between Tcells and antigen-presenting cells (APCs) [27]. Confavreux et al. [28] conducted a study in which 1088 patients were assessed for the effectiveness of teriflunomide. The annual relapse rate and disability improvement were noticed. After two years, the results showed a significant reduction in relapse rate, disability progression, and disease activity on MRI. Another study was conducted in France [29], in which they assessed the efficacy of teriflunomide in patients recruited from 189 sites in 26 countries and randomly assigned into the placebo group, teriflunomide $7 \mathrm{mg}$, and $14 \mathrm{mg}$ in a ratio of 1:1:1. Primary endpoints were relapse rate and disability progression. Results showed a better efficacy of $14 \mathrm{mg}$ in preventing relapse and improving disability. Teriflunomide should not be provided due to the danger of hepatotoxicity to patients with chronic liver diseases and is also contraindicated due to teratogenicity in pregnant females [30].

Siponimod

Siponimod is similar to fingolimod but more selective, and it was approved by the FDA in March 2019 for adults with RRMS, SPMS, and clinically isolated syndromes [31]. Several studies were conducted to determine the effectiveness of siponimod in RRMS and these showed that it can reduce the frequency of relapse and brain lesions on MRI [32]. Siponimod is contraindicated in patients with CYP2CP9*3/*3 or those with advanced heart failure, myocardial infarction, stroke, or transient ischemic attack (TIA) [33]. 
It was first approved by the FDA in March 2019 for the treatment of RRMS and SPMS. It is a purine antimetabolite, hence acting as an immunosuppressive agent and decreasing the lymphocyte count [34]. Giovannoni et al. [35] in their trial included 1326 adults with RRMS in a randomized double-blind study showed the efficacy of cladribine. Patients were given $3.5 \mathrm{mg} / \mathrm{kg}$ or $5.25 \mathrm{mg} / \mathrm{kg}$ of cladribine or placebo. Primary endpoints assessed at 96 weeks showed a decrease in relapse rate, disability progression, and MRI lesions. Mild to moderate lymphocytopenia was also seen with a high and low dose of cladribine.

\section{Infusion therapies}

Infusion therapies comprise a group of medications that acts against B-cells to suppress the autoimmune response. Several drugs have been tested for treatment in MS, including natalizumab, alemtuzumab, ocrelizumab, and rituximab. Natalizumab was approved by the FDA in November 2005 and is directed against integrin molecules, resulting in decreased adhesion and the migration of leukocytes. Alemtuzumab was approved by the FDA in November 2014, and it is a humanized monoclonal antibody that causes the depletion of CD52-expressing T-cells, B-cells, natural killer cells, and monocytes [24]. Ocrelizumab was approved by the FDA in March 2017 and is a recombinant human anti-CD20 (a B-cell marker) monoclonal antibody. It optimizes B-cell depletion by the modification of the Fc region, which enhances antibodydependent cell-mediated cytotoxicity and reduces complement-dependent cytotoxicity. Rituximab was approved by the FDA for multiple disorders, but it is also used by neurologists as off-label, and it has a similar mechanism of action as ocrelizumab [36]. The literature search and original articles for the use of infusion therapies in RRMS are summarized below (Table 4).

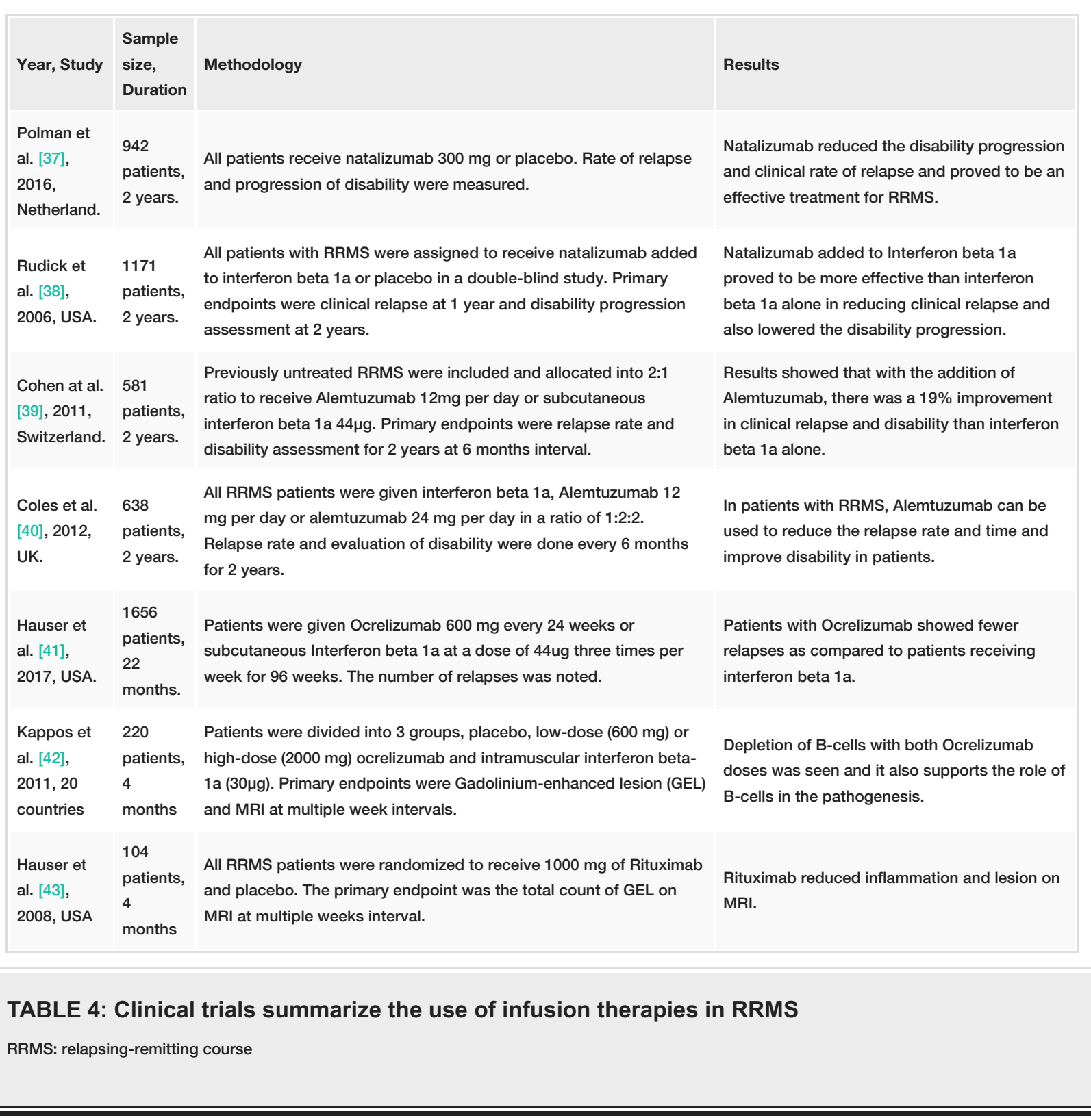




\section{Others}

Several immunosuppressants and immunomodulators have been evaluated for RRMS treatment, including mitoxantrone, cyclophosphamide, azathioprine, methotrexate, and mycophenolate mofetil. However, only the first three have shown better efficacy in the treatment of RRMS and are described below.

\section{Mitoxantrone}

Mitoxantrone was approved by the FDA in 2000 for treatment of RRMS. Its mechanism of action is manyfold; it inhibits topoisomerase II, intercalates deoxyribonucleic acid (DNA), and suppresses immune cells and secretions of cytokines. Its efficacy in the treatment of RRMS is questionable due to its increased adverse effects [44]. Thus, it is only considered as a last resort in patients with a rapidly progressing disease where other medications have failed.

\section{Cyclophosphamide}

This drug is unique in its blood-brain barrier-crossing property. Its mechanism of action is due to immunosuppression by shifting the Th1 to a Th2 response and breaking the DNA. It has a good early-stage effect in which inflammation is superseded by degeneration. It is usually used as pulse therapy in patients who are not responding to INFs or GA [45]. In a study by Krishnan et al., patients with RRMS were treated at a dose of $50 \mathrm{mg} / \mathrm{kg} /$ day with IV cyclophosphamide for four days and then a leukocyte colony-stimulating factor was given. After 23 months, patients were evaluated and significant disability reduction was noted [46] but more studies are needed to determine its effectiveness.

Azathioprine

It is used as an alternative to interferon (INF) in some patients of RRMS. It is a purine analog that inhibits DNA synthesis and suppresses immunity. Casetta et al. [47] in their systematic review included five randomized control trials with 698 patients. The azathioprine group showed a significant reduction in relapses of MS patients as compared to placebo when observed at the first, second, and third years of treatment. In one trial, it was found that if azathioprine is given at a dose of $3 \mathrm{mg} / \mathrm{kg} / \mathrm{day}$, it can significantly reduce lesions in MRI [48].

\section{Autologous stem cell transplantation}

Stem cells have been well-investigated for the treatment of RRMS. The basic concept behind this therapy is harvesting the patient's own blood cells, treating these cells with chemotherapy and biologics to destroy autoimmune cells, and the reinfusion of these stem cells into patients to regenerate the immune system. Several studies have been conducted to explain the role of stem cells in the treatment of MS Burt et al. [49] in their study included 110 patients with two relapses while being treated with conventional treatment. These patients were observed for a year and the Expanded Disability Status Scale (EDSS) was measured at six months and one year. They concluded that treatment with stem cells results in a prolonged time to disease progression. In their study, Nash et al. [50] included 24 patients with refractory RRMS. These patients were given high-dose immunosuppression and resulted in a three and five event-free survival year (78\% and 69\%, respectively) and improvements in neurologic function [50]. However, to illustrate the cost-benefit result, these trials are limited and more data is required to make it conventional.

\section{Conclusions}

The treatment of frequent relapses in patients with MS is a common challenge for neurologists. Many studies have been conducted to evaluate treatment options that can decrease the frequency of relapses and improvement in radiological lesions. All therapeutic options have been focussed on slowing neurodegeneration and decreasing inflammation. However, to give promising options to RRMS patients, we still need standard guidelines for dosage, frequency, and add-on treatment options.

\section{Additional Information \\ Disclosures}

Conflicts of interest: In compliance with the ICMJE uniform disclosure form, all authors declare the following: Payment/services info: All authors have declared that no financial support was received from any organization for the submitted work. Financial relationships: All authors have declared that they have no financial relationships at present or within the previous three years with any organizations that might have an interest in the submitted work. Other relationships: All authors have declared that there are no other relationships or activities that could appear to have influenced the submitted work.

\section{References}

1. Haider L, Zrzavy T, Hametner S, et al.: The topography of demyelination and neurodegeneration in the multiple sclerosis brain. Brain. 2016, 139:807-815. 10.1093/brain/awv398 
2. Dilokthornsakul P, Valuck RJ, Nair KV, Corboy JR, Allen RR, Campbell JD: Multiple sclerosis prevalence in the United States commercially insured population. Neurology. 2016, 86:1014-1021.

10.1212/WNL.0000000000002469

3. Mahad DH, Trapp BD, Lassmann H: Pathological mechanisms in progressive multiple sclerosis . Lancet Neurol. 2015, 14:183-193. 10.1016/S1474-4422(14)70256-X

4. Adamec I, Crnošija L, Junaković A, Skorić MK, Habek M: Progressive multiple sclerosis patients have a higher burden of autonomic dysfunction compared to relapsing remitting phenotype. Clinic Neurophysiol. 2018, 129:1588-1594. 10.1016/j.clinph.2018.05.009

5. Pappas DJ, Oksenberg JR: Multiple sclerosis pharmacogenomics: maximizing efficacy of therapy . Neurology. 2010, 74:62-69. 10.1212/WNL.0b013e3181c980fb

6. Dhib-Jalbut S, Marks S: Interferon- $\beta$ mechanisms of action in multiple sclerosis . Neurology. 2010, 74:17-24. 10.1212/WNL.0b013e3181c97d99

7. Calabresi PA, Kieseier BC, Arnold DL, et al.: Pegylated interferon beta-1a for relapsing-remitting multiple sclerosis (ADVANCE): a randomized, phase 3, double-blind study. Lancet Neurol. 2014, 13:657-665. 10.1016/S1474-4422(14)70068-7

8. Moccia M, Palladino R, Carotenuto A, Saccàa F, Russoa CV, Lanzilloa R, Morraa VB: An 8-year retrospective cohort study comparing interferon- $\beta$ formulations for relapsing-remitting multiple sclerosis. Mult Scler Relat Disord. 2018, 19:50-54. 10.1016/j.msard.2017.11.006

9. Drulovic J, Kostic J, Mesaros S, Basuroski ID, Stojsavljevic N, Kisic-Tepavcevic D, Pekmezovic T: Interferonbeta and disability progression in relapsing-remitting multiple sclerosis. Clinic Neurol Neurosurg. 2013, 115:65-69. 10.1016/j.clineuro.2013.09.024

10. Saida T, Kira JI, Ueno Y, Harada N, Hirakata T: Long-term efficacy and safety of intramuscular interferon beta- 1a: randomized postmarketing trial of two dosing regimens in Japanese patients with relapsingremitting multiple sclerosis. Mult Scler Relat Disord. 2016, 7:102-108. 10.1016/j.msard.2016.02.002

11. Traboulsee A, Li DK, Cascione M, Fang J, Dangond F, Miller A: Effect of interferon beta-1a subcutaneously three times weekly on clinical and radiological measures and no evidence of disease activity status in patients with relapsing-remitting multiple sclerosis at year 1. BMC Neurol. 2018, 18:143. 10.1186/s12883018-1145-X

12. Aharoni R: Immunomodulation neuroprotection and remyelination - the fundamental therapeutic effects of glatiramer acetate: a critical review. J Autoimmun. 2014, 54:81-92. 10.1016/j.jaut.2014.05.005

13. Río J, Rovira A, Tintoré M, et al.: Evaluating the response to glatiramer acetate in relapsing-remitting multiple sclerosis (RRMS) patients. Mult Scler J. 2014, 20:1602-1608. 10.1177/1352458514527863

14. Wolinsky JS, Borresen TE, Dietrich DW, et al.: GLACIER: an open-label, randomized, multicenter study to assess the safety and tolerability of glatiramer acetate $40 \mathrm{mg}$ three-times weekly versus $20 \mathrm{mg}$ daily in patients with relapsing-remitting multiple sclerosis. Mult Scler Relat Disord. 2015, 4:370-376. 10.1016/j.msard.2015.06.005

15. Ziemssen T, Bajenaru OA, Carrá A, et al.: A 2-year observational study of patients with relapsing-remitting multiple sclerosis converting to glatiramer acetate from other disease-modifying therapies: the COPTIMIZE trial. J Neurol. 2014, 261:2101-2111. 10.1007/s00415-014-7446-0

16. Davis MD, Ashtamker N, Steinerman JR, Knappertz V: Time course of glatiramer acetate efficacy in patients with RRMS in the GALA study. Neurol Neuroimmunol Neuroinflamm. 2017, 4:327. 10.1212/NXI.0000000000000327

17. Ehling R, Di Pauli F, Lackner P, et al.: Impact of glatiramer acetate on paraclinical markers of neuroprotection in multiple sclerosis: a prospective observational clinical trial. J Neuroimmunol. 2015, 15:98-105. 10.1016/j.jneuroim.2015.08.004

18. Cohen JA, Chun J: Mechanisms of fingolimod's efficacy and adverse effects in multiple sclerosis . Ann Neurol. 2011, 69:759-777. 10.1002/ana.22426

19. Kappos L, Radue E, O'Connor P, et al.: A placebo-controlled trial of oral fingolimod in relapsing multiple sclerosis. New Eng J Med. 2010, 5:387-401. 10.1056/NEJMoa0909494

20. Saida T, Kikuchi S, Itoyama Y, et al.: A randomized, controlled trial of fingolimod (FTY720) in Japanese patients with multiple sclerosis. Mult Scler J. 2012, 362:387-401. 10.1177/1352458511435984

21. Kappos L, Antel J, Comi G, et al.: Oral fingolimod (FTY720) for relapsing multiple sclerosis . New Eng J Med. 2006, 11:1124-1140. 10.1056/NEJMoa052643

22. Cohen JA, Barkhof F, Comi G: Oral fingolimod or intramuscular interferon for relapsing multiple sclerosis . New Eng J Med. 2010, 362:402-415. 10.1056/NEJMoa0907839

23. Scannevin RH, Chollate S, Jung MY, et al.: Fumarates promote cytoprotection of central nervous system cells against oxidative stress via the nuclear factor (erythroid-derived2)-like 2 pathway. J Pharmacol Exp Ther. 2012, 341:274-248. 10.1124/jpet.111.190132

24. Fox RJ, Miller DH, Phillips JT, et al.: Placebo-controlled phase 3 study of oral BG-12 or glatiramer in multiple sclerosis. New Eng J Med. 2012, 1:1087-1097. 10.1056/NEJMoa1206328

25. Gold R, Kappos L, Arnold DL, et al.: Placebo-controlled phase 3 study of oral BG-12 for relapsing multiple sclerosis. New Eng J Med. 2012, 12:1098-1107. 10.1056/NEJMoa1114287

26. Muñoz MA, Kulick CG, Kortepeter CM, Levin RL, Avigan MI: Liver injury associated with dimethyl fumarate in multiple sclerosis patients. Mult Scler J. 2017, 14:1947-1949. 10.1177/1352458516688351

27. Zeyda M, Poglitsch M, Geyeregger R, et al.: Disruption of the interaction of $\mathrm{T}$ cells with antigen-presenting cells by the active leflunomide metabolite teriflunomide: involvement of impaired integrin activation and immunologic synapse formation. Arthritis Rheum. 2005, 9:2730-2739. 10.1002/art.21255

28. O'Connor P, Wolinsky JS, Confavreux C, et al.: Randomized trial of oral teriflunomide for relapsing multiple sclerosis. New Eng J Med. 2011, 14:1293-1303. 10.1056/NEJMoa1014656

29. Confavreux C, O'Connor P, Comi G, et al.: Oral teriflunomide for patients with relapsing multiple sclerosis (TOWER): a randomized, double-blind placebo-controlled, phase 3 trial. Lancet Neurol. 2014, 3:247-256. 10.1016/S1474-4422(13)70308-9

30. He D, Zhang C, Zhao X, Zhang Y, Dai Y, Li Y, Chu L: Teriflunomide for multiple sclerosis . Cochrane Database Syst Rev. 2016, 3:CD009882. 10.1002/14651858.CD009882.pub3 
31. The U.S. Food and Drug Administration: FDA approves new oral drug to treat multiple sclerosis . (2019). Accessed: March 26, 2019: https://www.fda.gov/news-events/press-announcements/fda-approves-neworal-drug-treat-multiple-sclerosis.

32. Kappos L, Bar-Or A, Cree BA, et al.: Siponimod versus placebo in secondary progressive multiple sclerosis (EXPAND): a double-blind, randomized, phase 3 study. Lancet. 2018, 391:1263-1273. 10.1016/S01406736(18)30475-6

33. Selmaj K, Li DK, Hartung HP, et al.: Siponimod for patients with relapsing-remitting multiple sclerosis (BOLD): an adaptive, dose-ranging, randomized, phase 2 study. Lancet Neurol. 2013, 8:756-767. 10.1016/S1474-4422(13)70102-9

34. The U.S. Food and drug administration. FDA approves new oral treatment for multiple sclerosis . (2019). Accessed: April 3, 2019: https://www.fda.gov/NewsEvents/Newsroom/PressAnnouncements/ucm634837.htm.

35. Giovannoni G, Comi G, Cook S, et al.: A placebo-controlled trial of oral cladribine for relapsing multiple sclerosis. New Eng J Med. 2010, 5:416-426. 10.1056/NEJMoa0902533

36. Bielekova B, Becker BL: Monoclonal antibodies in MS: mechanisms of action . Neurol. 2010, 74:31-40. 10.1212/WNL.0b013e3181c97ed3

37. Polman CH, O'Connor PW, Havrdova E, et al.: A randomized, placebo-controlled trial of natalizumab for relapsing multiple sclerosis. New Eng J Med. 2006, 9:899-910. 10.1056/NEJMoa044397

38. Rudick RA, Stuart WH, Calabresi PA, et al.: Natalizumab plus interferon beta-1a for relapsing multiple sclerosis. New Eng J Med. 2006, 9:911-923. 10.1056/NEJMoa044396

39. Cohen JA, Coles AJ, Arnold DL, et al.: Alemtuzumab versus interferon beta 1a as first-line treatment for patients with relapsing-remitting multiple sclerosis: a randomized controlled phase 3 trial. Lancet. 2012, 380:1819-1828. 10.1016/S0140-6736(12)61769-3

40. Coles AJ, Twyman CL, Arnold DL, et al.: Alemtuzumab for patients with relapsing multiple sclerosis after disease-modifying therapy: a randomized controlled phase 3 trial. Lancet. 2012, 380:1829-1839. 10.1016/S0140-6736(12)61768-1

41. Hauser SL, Bar-Or A, Comi G, et al.: Ocrelizumab versus interferon beta-1a in relapsing multiple sclerosis . New Eng J Med. 2017, 3:221-234. 10.1056/NEJMoa1601277

42. Kappos L, Li D, Calabresi PA, et al.: Ocrelizumab in relapsing-remitting multiple sclerosis: a phase 2, randomized, placebo-controlled, multicentre trial. Lancet. 2011, 378:1779-1787. 10.1016/S01406736(11)61649-8

43. Hauser SL, Waubant E, Arnold DL, et al.: B-cell depletion with rituximab in relapsing-remitting multiple sclerosis. New Eng J Med. 2008, 7:676-688. 10.1056/NEJMoa0706383

44. Goodin DS, Arnason BG, Coyle PK, Frohman EM, Paty DW: The use of mitoxantrone (Novantrone) for the treatment of multiple sclerosis: report of the Therapeutics and Technology Assessment Subcommittee of the American Academy of Neurology. Neurol. 2003, 10:1332-1338. 10.1212/01.WNL.0000095425.84407.39

45. Bahr U, Schulten HR, Hommes OR, Aerts F: Determination of cyclophosphamide in urine, serum and cerebrospinal fluid of multiple sclerosis patients by field desorption mass spectrometry. Clinica Chimica Acta. 1980, 2:183-192. 10.1016/0009-8981(80)90212-0

46. Krishnan C, Kaplin AI, Brodsky RA, et al.: Reduction of disease activity and disability with high-dose cyclophosphamide in patients with aggressive multiple sclerosis. Arch Neurol. 2008, 8:1044-1051. 10.1001/archneurol.65.8.noc80042

47. Casetta I, Iuliano G, Filippini G: Azathioprine for multiple sclerosis. Cochrane Database Syst Rev. 2007, 4:CD003982. 10.1002/14651858.CD003982.pub2

48. Massacesi L, Parigi A, Barilaro A, et al.: Efficacy of azathioprine on multiple sclerosis new brain lesions evaluated using magnetic resonance imaging. Arch Neurol. 2005, 12:1843-1847. 10.1001/archneur.62.12.1843

49. Burt RK, Balabanov R, Burman J, et al.: Effect of nonmyeloablative hematopoietic stem cell transplantation vs continued disease-modifying therapy on disease progression in patients with relapsing-remitting multiple sclerosis: a randomized clinical trial. JAMA. 2019, 2:165-174. 10.1001/jama.2018.18743

50. Nash RA, Hutton GJ, Racke MK, et al.: High-dose immunosuppressive therapy and autologous HCT for relapsing-remitting MS. Neurology. 2017, 9:842-852. 10.1212/WNL.0000000000003660 